\title{
Carbonyl sulfide and dimethyl sulfide exchange between lawn and the atmosphere
}

\author{
Chunmei Geng and Yujing $\mathrm{Mu}$ \\ Research Center for Eco-Environmental Sciences, Chinese Academy of Sciences, Beijing, China
}

Received 23 December 2003; revised 11 March 2004; accepted 3 May 2004; published 19 June 2004.

[1] The exchange of carbonyl sulfide (COS) between lawn and the atmosphere was investigated by using a static enclosure under natural field conditions. The results indicated that the lawn acted as a sink for atmospheric COS and a source of dimethyl sulfide (DMS). The exchange fluxes of COS and DMS ranged between $-3.24 \mathrm{pmol} \mathrm{m}^{-2} \mathrm{~s}^{-1}$ and $-94.52 \mathrm{pmol} \mathrm{m}^{-2} \mathrm{~s}^{-1}$, and between 0 and $3.14 \mathrm{pmol} \mathrm{m}^{-2} \mathrm{~s}^{-1}$, respectively. The lawn was capable of continuously absorbing COS in nighttime as well as in daytime. The COS fluxes depended strongly on the ambient COS mixing ratios. The dependency of DMS emission fluxes on temperature was observed in November 2002. Soil also acted as a sink for COS during our study. However, the COS exchange fluxes of the lawn were much higher than that of the soil. The average COS and DMS fluxes were much higher in spring than in autumn and in summer. The daytime vertical profiles of COS also indicated that the lawn acted as a net sink for COS. INDEX TERMS: 0315 Atmospheric Composition and Structure: Biosphere/atmosphere interactions; 0322 Atmospheric Composition and Structure: Constituent sources and sinks; 1610 Global Change: Atmosphere (0315, 0325); KEYWORDS: carbonyl sulfide, dimethyl sulfide, exchange rate

Citation: Geng, C., and Y. Mu (2004), Carbonyl sulfide and dimethyl sulfide exchange between lawn and the atmosphere, J. Geophys. Res., 109, D12302, doi:10.1029/2003JD004492.

\section{Introduction}

[2] Atmospheric sulfur (S) cycling is largely linked to the activities of various biological processes occurring on the Earth's surface. Carbonyl sulfide (COS) and dimethyl sulfide (DMS) are the most relevant reduced volatile $\mathrm{S}$ compounds involved in these interactive processes [de Mello and Hines, 1994].

[3] COS is the most abundant reduced sulfur compound and nearly inert to photochemical decomposition in the troposphere. It has been proposed as the major nonvolcanic source of stratospheric sulfate aerosols [Crutzen, 1976; Berresheim and Vulcan, 1992; Fried et al., 1993]. Stratospheric aerosols are known to influence the Earth's radiation balance and provide surface area for chemical reactions which enhance the depletion of stratospheric ozone [Turco et al., 1980; Roche, 1994; Solomon et al., 1993].

[4] DMS has been hypothesized to be the principle precursor of cloud condensation nuclei $(\mathrm{CCN})$ in the marine troposphere, which is potentially important in regulating cloud optical properties and climate [de Mello and Hines, 1994].

[5] For COS, the total global sources and sinks are estimated as $1.31 \pm 0.25$ and $1.66 \pm 0.79 \mathrm{Tg} \mathrm{a}^{-1}$, respectively. However, the COS exchange fluxes for soils and vegetation are still sparse [Watts, 2000]. The emissions of DMS from vegetation are also a little uncertain, as there

Copyright 2004 by the American Geophysical Union. 0148-0227/04/2003JD004492 seems an almost total dearth of data from temperate and boreal regions [Watts, 2000].

[6] The object of this study was to measure the exchange fluxes of COS and DMS between air and the lawn in Beijing city. The factors affecting the fluxes of the two gases, i.e., photosynthetically active radiation (PAR), temperature and COS ambient concentration, were also investigated.

\section{Experiment}

\subsection{Sampling Site}

[7] This study was conducted on the cultivated lawn in the north of Beijing city $\left(116^{\circ} \mathrm{E}, 40^{\circ} \mathrm{N}\right)$. All measurements took place from November 2002 to June 2003. The lawn was $20 \mathrm{~m}$ south of our laboratory building and was taken care of by gardeners. The lawn was watered about every week when there was no rain. So the lawn was considered moist at all times. No fertilizer was applied to the lawn during our experiment. The grass was mowed about every three weeks. Investigated soil was just inside the lawn and both grass and the roots were removed in order to avoid the roots' influence on the microbial activity and the trace gas fluxes. Soil characteristics of the lawn, based on soil analysis according to standard protocols [Liu, 1996], are as follows: $\mathrm{pH}$ : $8.60, \mathrm{~S}_{\text {total }}: 202 \mathrm{mg} / \mathrm{Kg}, \mathrm{C}_{\text {organic }}: 713 \mathrm{mg} / \mathrm{Kg}$, $\mathrm{N}_{\text {total }}: 79 \mathrm{mg} / \mathrm{Kg}$.

\subsection{Enclosure System}

[8] A static enclosure was used to measure the emission or consumption of COS and DMS between the lawn and 
the atmosphere. The enclosure $(0.40 \mathrm{~m} \times 0.40 \mathrm{~m} \times 0.42 \mathrm{~m})$ was constructed of Teflon ${ }^{\circledR}$ film with an aluminum bracket, which was also wrapped by Teflon film to insure the air in the enclosure only contact with Teflon film and the lawn. The enclosure walls were not rigid and thus wall flexing, both manually and by the wind, were sufficient to effect uniform mixing. Fried et al. [1993] had confirmed that in all cases mixing occurred rapidly without the need for additional mechanical stirring for this kind of enclosure. The enclosure was placed on Teflonlined aluminum collar, which was installed in the site before field campaigns began. Using a metal bellows pump, five samples ( $\sim 900 \mathrm{ml}$ for each sample) were drawn at $1 \mathrm{~L} \mathrm{~min}^{-1}$ from the enclosure headspace at $\sim 0$, $5,10,20$, and $30 \mathrm{~min}$ after the enclosure was deployed in autumn. Because the temperature inside the static enclosure rose quickly with strong sunshine, most samples were collected at $0,5,10,15$, and $20 \mathrm{~min}$ in spring and summer. All samples were collected into Teflon bags (the volume of the bag is $1 \mathrm{~L}$ ). Because the enclosure was made of Teflon film, which has good flexibility, the pressure change (4 or 5 liters account for only $6-7 \%$ of the total volume) caused by sampling may be negligible. These collected samples were analyzed within 2 hours in the laboratory. The metal bellows pump and the Teflon bag were tested for COS and DMS production or destruction, and no interference was found for COS and DMS during a short time contact (1 minute for the pump and 2 hours for the bag). Air temperature within the enclosure was recorded with a thermocouple. PAR was measured with a LI-COR quantum sensor (LI-COR, Lincoln, NE, USA) outside the enclosure. A thermometer showed the temperature underground at $5 \mathrm{~cm}$.

\subsection{Analysis of the Trace Gases}

[9] The COS and DMS in the bags were immediately sampled by cryogenic trapping and analyzed by means of a gas chromatograph (GC) equipped with a flame photometric detector (FPD). Detailed description of the method may be found in the work of $\mathrm{Mu}$ et al. [2002], and therefore is only briefly described here. The $800 \mathrm{~mL}$ air sample in the bag was preconcentrated onto a Teflon absorption tube filled with Tenax-GC, which was immersed in liquid nitrogen. To remove water and some strong oxidants, such as $\mathrm{O}_{3}$ and nitrogen oxides $\left(\mathrm{NO}_{x}\right)$, a glass tube filed with calcium chloride $\left(\mathrm{CaCl}_{2} \cdot 2 \mathrm{H}_{2} \mathrm{O}\right)$ and a glass fiber filter coated with 5\% KI and 5\% glycerol were placed in front of the sample line [Kittler et al., 1992]. Prior to analysis, the adsorption tube was removed from the liquid nitrogen after trapping of the sulfur volatiles and stayed at room temperature for about $0.5 \mathrm{~min}$ to allow the liquid nitrogen to evaporate out of the tube. The trap tube, still cold, was then immediately inserted into one injection port of the GC. The injection port of the GC was as thermal heater (desorption), which connected with a six-port valve. The adsorbed COS and DMS was thermally liberated for $\sim 0.5 \mathrm{~min}$ and transferred into the GC column through the six-way valve. The chromatographic separation was conducted using temperature gradient on a glass column $(3 \mathrm{~m} \times 4 \mathrm{~mm})$ packed with $20 \%$ SE-30 on Chromosorb P (60-80 mesh). Optimum separation was obtained by starting the temperature program at $50^{\circ} \mathrm{C}$, holding for $10 \mathrm{~min}$, and then heating at $10^{\circ} \mathrm{C} \min ^{-1}$ up to $143^{\circ} \mathrm{C}$. The injection port temperature and the detector temperature were $180^{\circ} \mathrm{C}$ and $240^{\circ} \mathrm{C}$, respectively. Typical gas flow rates were: nitrogen (carrier

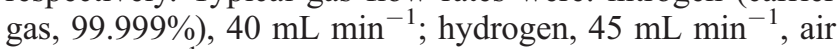

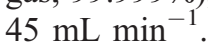

[10] $\mathrm{CO}_{2}$ was measured by using a GC-Ni catalyst converter-FID (GC 112A, Shanghai Precision and Scientific Instrument Co. Ltd.) with $1 \mathrm{ml}$ direct injection. Typical gas flow rates were: nitrogen (carrier gas, 99.999\%), $52 \mathrm{~mL} \mathrm{~min}^{-1}$; hydrogen, $17 \mathrm{~mL} \mathrm{~min}^{-1}$; compressed air, $252 \mathrm{~mL} \mathrm{~min}^{-1}$.

[11] Control measurements of the empty enclosure were conducted regularly in order to evaluate possible enclosure loss or contamination problem of COS inside the enclosure. Before field campaigns had begun at every season, we used a piece of Teflon film as the bottom of the chamber. Samples were collected at $0,5,10,20$, and $30 \mathrm{~min}$ and analyzed. The relative precisions were $<6 \%$, which was within the precision of our system.

[12] DMS was from Germany with a purity of greater than $99 \%$ and further purified by repeat freeze-pump-thaw cycles and fractional distillation before use. The standard gas of DMS was prepared by mixing the vapor of DMS (the vapor pressure was measured by capacitance manometer, 0-10 Torr, MKS) in Nitrogen in a $10 \mathrm{~L}$ glass-tight bulb. DMS concentration prepared inside the bulb was $115.76 \mathrm{mmol} / \mathrm{l}$. The standard material of COS $(2 \%, \mathrm{COS} /$ $\mathrm{N}_{2}$ ), from Scott Specialty Gases, Inc., had a certified accuracy of less than $\pm 5 \%$. The accuracy of our flow dilution is less than $\pm 5 \%$. The above standard gas samples were further diluted by using high-grade nitrogen in a Teflon bag to be $7.23 \mathrm{pmol} / 1$ and $111.61 \mathrm{pmol} / 1$ for DMS and COS, respectively. Calibration lines $\left(\log _{\text {Area }}-\log _{\text {dose }}\right)$ for COS and DMS was obtained by injection of different enriched volume of the diluted gas samples. These concentrations were comparable to those measured in field study. The analytical column employed in this study has been found to efficiently separate various volatile sulfur compounds $\left(\mathrm{H}_{2} \mathrm{~S}, \mathrm{COS}, \mathrm{CS}_{2}\right.$, thiols, sulfides, disulfides, et al. $)$ [Tangerman, 1986; Mu et al., 2002]. The recovery efficiencies were tested by using 0.5 ppmv samples for COS and DMS. Comparing the respond values between direct injection $(1 \mathrm{ml})$ and the injection of the same amounts performed via concentration onto Tenax-GC, the recovery efficiencies of COS and DMS were $\sim 94 \%$ and $100 \%$, respectively. The detection limits for COS and DMS were $\sim 0.88$ pmol L$^{-1}$ and $0.12 \mathrm{pmol} \mathrm{L}^{-1}$ (800 $\mathrm{ml}$ gas sample), respectively. The relative precisions of the method for COS and DMS were $<6 \%$ (the relative precision for COS based on reproducibility of consecutive samples over a 30-day period with a compressed air sample of $907 \mathrm{pptv}$ (number of replicates $\mathrm{n}=30$ ); for DMS based on reproducibility of a sample with 150 pptv $(n=6))$.

\subsection{Flux Calculation}

[13] The gas exchange rate $F$ in the enclosure was calculated using the following equation:

$$
F=H[d C / d t] t=0,
$$

where $H$ is the enclosure geometry factor, i.e., the ratio of the enclosure volume to the enclosure soil area and $d C / d t$ is the slope of the curve of the gas concentration change with 
time in the enclosure headspace, assuming a uniformly mixed condition therein (convective mixing) as a function of time $(t)$.

[14] The following assumptions were made to calculate the errors of the exchange rates: $6 \%$ error for the two gases measurements $\left(\sigma_{\mathrm{b}}\right), 5 \%$ error in volume of enrichment $\left(\sigma_{\mathrm{Q}}\right)$, and $1 \%$ in the surface area determination $\left(\sigma_{a}\right)$. The total flux error $\left(\sigma_{F}\right)$ can be obtained by using the following error propagation method according to Doerffel [1984]:

$$
\sigma_{F}=\sqrt{\sigma_{b}^{2}+\sigma_{\mathrm{Q}}^{2}+\sigma_{a}^{2}}
$$

\section{Results and Discussion}

[15] The COS and DMS fluxes were calculated based on five or four headspace air samples (i.e., $n=5$ or $n=4$ ). Nonlinear relationship between the COS and DMS concentrations and deployed time was observed in daytime. Goldan et al. [1987] pointed out that temperature variations alone greatly affect $\mathrm{S}$ gas fluxes. The temperature inside the enclosure would increase after the enclosure was deployed in daytime. This temperature changes might result in the observed nonconstant slope. This viewpoint could be certified by our measurement in the cold early morning and at dusk, when the temperature in the chamber was relative constant, COS and DMS concentrations within static enclosure versus time were linear. In addition, the change of COS concentration in the chamber could also influence on COS uptake rate [Kesselmeier et al., 1999] and result in the observed nonconstant slope.

[16] Remde et al. [1996] and Conrad [1994] pointed out gas exchange can be discussed as a result of simultaneously operating production and consumption process. This implies the existence of a so-called compensation point, which is an ambient concentration where the consumption and production balance each other and the net flux is zero. The applicability of this concept has been empirically confirmed for exchange of COS in plants [Goldan et al., 1988; Kesselmeier and Merk, 1993; Kesselmeier et al., 1999]. The grass as one kind of plants should be has a compensation point. The lowest COS concentration in the enclosure was $190 \mathrm{pptv}$, which is higher than the compensation point for plants $(90-150 \mathrm{ppt})$ reported by Kesselmeier and Merk [1993]. Continuous decrease of COS concentration with time indicated the COS concentration in the enclosure was still above the compensation point for the grass.

[17] De Mello and Hines [1994] pointed out static enclosure system could mimic natural conditions at the time of initial sampling. The static enclosure system could partly eliminate the problem due to the change in the head gas composition by extrapolating to $t=0$. Although the time course curve is influenced by the feedback mechanism, short deployment times may reduce the effect. The deployment times for most flux measurement in daytime were $<20 \mathrm{~min}$ in this study. The concentration of $\mathrm{CO}_{2}$ in the chamber was always above $250 \mathrm{ppm}$. So the concomitant $\mathrm{CO}_{2}$ decrease inside the enclosure could not significantly affect the results. For the nonlinear, to calculate $[\mathrm{dC} / \mathrm{dt}]_{\mathrm{t}=0}$, the concentration versus time data were fitted to an exponential equation of the form

$$
C(t)=a-b e^{(-k t)}
$$

where $a=C_{\max }$, which is the COS concentration reached when the enclosure headspace equals the COS concentration in the atmosphere, $b=C_{\max }$ minus the COS concentration at $t=0\left(C_{\text {air }}\right)$, and $k=$ a rate constant. $C_{\max }$ and $k$ were iteratively derived by computer and then used to calculate $[d C / d t]_{t=0}$ from the equation

$$
[d C / d t]_{t=0}=k\left(C_{\max }-C_{\text {air }}\right)
$$

which was then used in equation (1) to calculate the flux in mass per unit area per time [de Mello and Hines, 1994]. The correlation coefficients $\left(R^{2}\right)$ ranged between 0.93 and 1 , but usually exceeded 0.98. Typical COS and DMS time course plots are displayed in Figure 1. The COS concentration inside the static enclosure decreased with time, while the DMS concentration inside the static enclosure increased with time.

[18] To determine the influence of mowing on the exchange fluxes, we measured the COS and DMS exchange rates before and after mowing. The COS uptake by the mowed lawn was very weak and occasionally weak emission was also observed. For DMS the mowed lawn always exhibited as a weak emission. The normal ability of the mowed lawn for COS uptake as well as DMS emission returned gradually after 4 days, so only the data 4 days after mowing were presented in this study.

[19] Diurnal and seasonal variations for COS and DMS exchange between the lawn and the atmosphere were investigated in this study. Temperature inside the chamber and underground at $5 \mathrm{~cm}, \mathrm{PAR}$ and $\mathrm{CO}_{2}$ assimilation were also measured simultaneously.

[20] The exchange rates of COS and DMS between the lawn and the atmosphere in daytime on a surface area basis observed in three seasons are listed in Table 1. Only the periods with continuous data under stable conditions were listed. The COS concentration in the static enclosure always decreased with time, indicating that COS was deposited to the lawn in all investigated circumstances. The exchange rates for COS in daytime and in the evening (PAR $=0 \mu \mathrm{mol} \mathrm{m} \mathrm{m}^{-2} \mathrm{~s}^{-1}$ ) were found to be in the range of 3.90-94.52 $\mathrm{pmol} \mathrm{m}^{-2} \mathrm{~s}^{-1}$ and 3.24-74.01 $\mathrm{pmol} \mathrm{m}^{-2} \mathrm{~s}^{-1}$, respectively. DMS concentrations in the static enclosure increased with time and the fluxes in daytime and in the evening were in the range of $0-3.14 \mathrm{pmol} \mathrm{m}^{-2} \mathrm{~s}^{-1}$ and $0-$ 1.42 , respectively. The deposition velocity of COS derived from the fluxes, and the COS mixing ratios were in the range from 0.13 to $2.05 \mathrm{~mm} \mathrm{sec}^{-1}$ in daytime and from 0.11 to $0.81 \mathrm{~mm} \mathrm{sec}^{-1}$ in the evening, respectively, The deposition velocities of COS obtained by this study were in good agreement with other laboratory and field studies (see Table 2).

[21] It is known that many higher plants release $\mathrm{H}_{2} \mathrm{~S}$ into the atmosphere as a result of the higher plant Carbonic Anhydrase (CA) enzyme reacting with COS instead of (sometimes in preference to) $\mathrm{CO}_{2}$ [Protoschill-Krebs et al., 1989; Kesselmeier and Merk, 1993]. CA in vivo splits COS into $\mathrm{CO}_{2}$ and $\mathrm{H}_{2} \mathrm{~S}$ and may feed the carboxylating enzymes [Protoschill-Krebs et al., 1989]. As grass belongs to higher plant, it is also entirely possible that the 


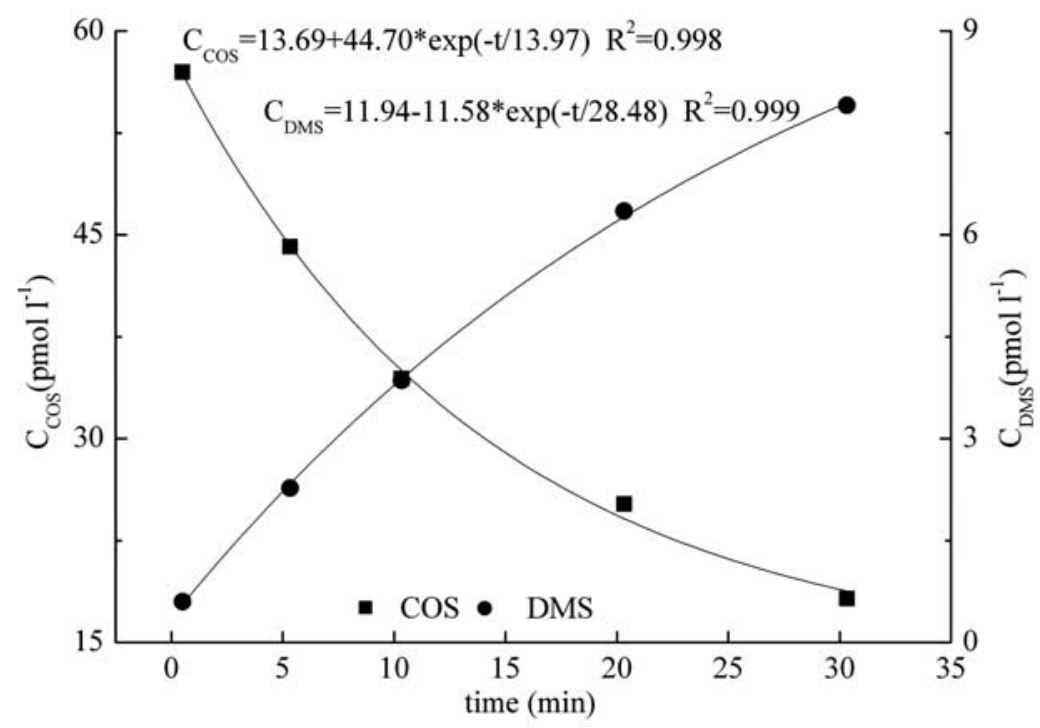

Figure 1. Typical carbonyl sulfide (COS) and dimethyl sulfide (DMS) concentration versus time curves, exponential fits, and corresponding equations during static enclosure measurements.

same mechanism is responsible for $\mathrm{COS}$ uptake and $\mathrm{H}_{2} \mathrm{~S}$ emission by the lawn. But in fact, we could obtain little $\mathrm{H}_{2} \mathrm{~S}$ data during our study.

\subsection{Carbonyl Sulfide (COS) Uptake by the Lawn}

[22] The COS mixing ratios in Beijing city strongly depended on weather condition, and varied from about $500 \mathrm{pptv}$ on windy and sunny days to several ppbv on stagnant days (such as cloudy days and nighttime). Because the COS exchange fluxes strongly depended on the COS mixing ratios (see next paragraph), in order to illustrate the effects of PAR, temperature and the assimilation of the lawn on the COS exchange rates, the COS deposition velocities were used in Figure 2, which shows the diurnal variations of the COS deposition velocities, as well as the exchange fluxes of DMS and $\mathrm{CO}_{2}$ on 19-20 June 2003.

[23] As has been shown by numerous studies, vegetation has to be regarded as a general sink for COS, a result that is confirmed by our studies. It was evident that COS deposition velocity has same trend with photosynthesis, which indicated that the COS deposition velocities in daytime was closely related to photosynthesis (Figure 2). Kuhn et al. [1996] assumed that the uptake of COS by higher plants was completely under stomatal control and considered the
COS exchange of higher vegetation during nighttime to be negligible. However, compared with the soil, the lawn had larger COS deposition velocities at night, this implied a light-independent process might exist for the grass. Protooschill-Krebs et al. [1989] pointed out that CA was a light-independent enzyme and CA-induced uptake of COS might occur independently from light. So besides stomatal regulation, light-independent regulation may exist and the COS uptake by higher vegetation during nighttime may not be negligible.

[24] The linear correlation between $\mathrm{COS}$ uptake and $\mathrm{CO}_{2}$ assimilation rate was significant $\left(R^{2}=0.69, n=11, \alpha=\right.$ 0.02 ) for the two days (Figure 2) and resulted in a ratio of $0.62 \mathrm{pmol} \mathrm{COS} / \mu \mathrm{mol} \mathrm{CO}$. This value was in good agreement with previous studies [Kuhn et al., 1996]. It should be mentioned that there was no linear correlation between COS uptake and $\mathrm{CO}_{2}$ assimilation rate for all data of this study. This may be due to large variation of $\mathrm{COS}$ mixing ratio in Beijing city. The ratios of $\mathrm{COS}$ uptake and $\mathrm{CO}_{2}$ assimilation

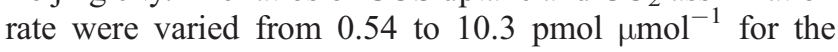
whole study.

[25] The exchange rate of COS strongly depended on ambient COS mixing ratio. Figure 3 shows the COS fluxes versus the COS mixing ratios in daytime during June. The

Table 1. Ranges of COS and DMS Uptake Rates $\left(\mathrm{pmol} \mathrm{m}^{-2} \mathrm{~s}^{-1}\right.$ ) Between the Lawn and the Atmosphere in Daytime on a Surface Area Basis Under Autumn, Spring and Summer Conditions at the Beijing Field Site ${ }^{\mathrm{a}}$

\begin{tabular}{|c|c|c|c|c|c|}
\hline Date & $\begin{array}{l}\text { COS Range, } \\
\text { pmol m}^{-2} \mathrm{~s}^{-1}\end{array}$ & $\begin{array}{l}\text { DMS Range, } \\
\text { pmol m } \mathrm{m}^{-2} \mathrm{~s}^{-1}\end{array}$ & 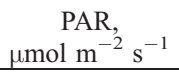 & $\mathrm{T}, \operatorname{deg} \mathrm{C}$ & $\begin{array}{c}\text { Ambient COS, } \\
\text { pmol } 1^{-1} \\
\end{array}$ \\
\hline 9 Nov. 2002 & $-52.14 \pm 13.06$ & $1.15 \pm 0.29$ & $61-460$ & $13.3 \pm 4.3$ & $49.8 \pm 10.8$ \\
\hline 10 Nov. 2002 & $-85.05 \pm 13.39$ & $1.38 \pm 0.22$ & $116-131$ & $11.2 \pm 1.3$ & $82.0 \pm 26.1$ \\
\hline 11 Nov. 2002 & $-15.07 \pm 3.82$ & $0.66 \pm 0.58$ & $51-434$ & $13.4 \pm 2.7$ & $23.1 \pm 1.67$ \\
\hline 8 Apr. 2003 & $-23.89 \pm 11.01$ & $2.06 \pm 0.88$ & $45-869$ & $19.5 \pm 4.8$ & $23.3 \pm 2.05$ \\
\hline 18 Apr. 2003 & $-33.23 \pm 12.94$ & $0.72 \pm 0.45$ & $320-1038$ & $16.6 \pm 3.3$ & $23.0 \pm 2.3$ \\
\hline 21 Apr. 2003 & $-42.00 \pm 7.61$ & $1.03 \pm 0.36$ & $597-1371$ & $21.9 \pm 6.2$ & $25.2 \pm 3.0$ \\
\hline 6 Jun. 2003 & $-36.60 \pm 9.48$ & $0.38 \pm 0.13$ & $93-600$ & $28.3 \pm 6.5$ & $33.5 \pm 6.8$ \\
\hline 7 Jun. 2003 & $-9.83 \pm 5.37$ & $0.32 \pm 0.07$ & $48-261$ & $23.2 \pm 1.8$ & $23.2 \pm 1.8$ \\
\hline 24 Jun. 2003 & $-11.34 \pm 1.22$ & $0.36 \pm 0.27$ & $779-936$ & $30.0 \pm 3.5$ & $21.0 \pm 2.9$ \\
\hline
\end{tabular}

${ }^{\mathrm{a}} \mathrm{COS}$, carbonyl sulfide; DMS, dimethyl sulfide; PAR, photosynthetically active radiation; $\mathrm{T}$, temperature 
Table 2. COS Uptake for Lawn in Comparison With Other Plant Species ${ }^{\mathrm{a}}$

\begin{tabular}{|c|c|c|c|c|}
\hline Species & $\begin{array}{c}\mathrm{COS} / \mathrm{CO}_{2}, \\
\mathrm{pmol} \mu \mathrm{mol}^{-1}\end{array}$ & $\begin{array}{l}\text { Deposition } \\
\text { Velocity, } \\
\text { mm sec }^{-1}\end{array}$ & $\begin{array}{l}\text { Light Intensity, } \\
\mu \mathrm{E} \mathrm{m}^{-2} \mathrm{~s}^{-1}\end{array}$ & Reference (Enclosure Conditions) \\
\hline Grass & $0.54-10.3$ & $0.11-2.05$ & $0-1448$ & this paper (field conditions) \\
\hline Quercus agrifolia & $\leq 2.7$ & $\leq 0.6$ & $\leq 200$ & Kuhn et al. [1996] (field conditions) \\
\hline Picea abies & & 0.5 & $\leq 350$ & Huber [1994] (field conditions) \\
\hline Phaseolus vulgaris & & 1.4 & $\overline{400}$ & Tylor et al. [1983] (laboratory conditions) \\
\hline Vegetables & & $0.25-0.6$ & 350 & Kluczewski et al. [1985] (laboratory conditions) \\
\hline Grass & & 0.75 & & \\
\hline Crops & & $1.3-3.3$ & 600 & Goldan et al. [1988] (laboratory conditions) \\
\hline Rapeseed & $0.9-1.4$ & $1.1-1.5$ & 600 & $\begin{array}{l}\text { Kesselmeier and Merk [1993] } \\
\text { (laboratory conditions) }\end{array}$ \\
\hline Corn & $1.9-16.7$ & $0.3-0.9$ & $150-1200$ & \\
\hline Sacoglottis gabonensis (canopy top) & $0.8-38.4$ & & & Kesselmeier et al. [1993] (laboratory conditions) \\
\hline Wheat & $4.3-6.7$ & & $100-250$ & Hofmann [1993] (laboratory conditions) \\
\hline
\end{tabular}

${ }^{a}$ Enclosure studies under laboratory and field conditions.
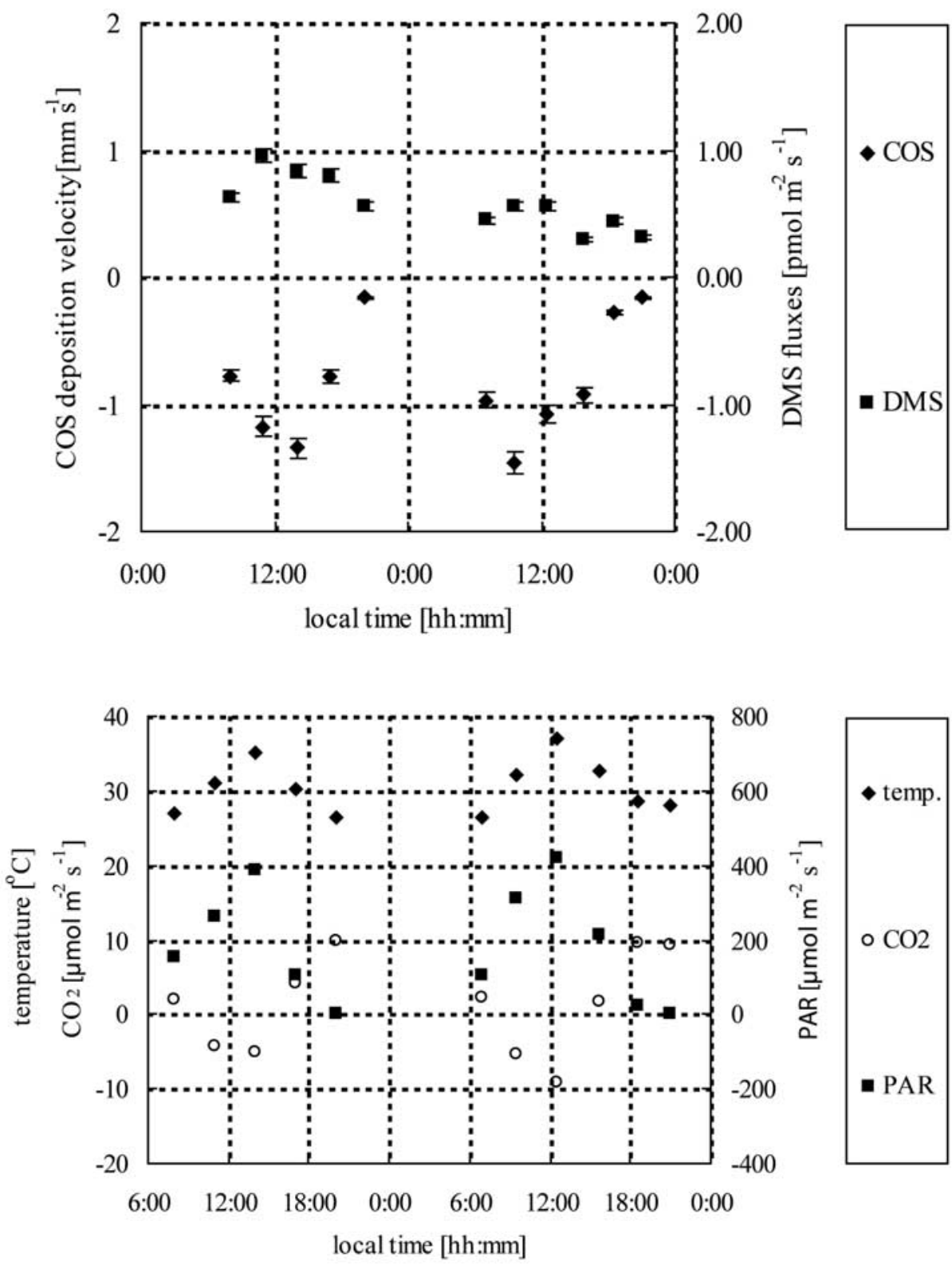

Figure 2. Diel cycle of the COS uptake and DMS emission by the lawn together with the ecophysiologically relevant parameters measured on 19-20 June 2003. Error bars of COS and DMS exchange indicate the total deposition velocity error according to equation (1). 


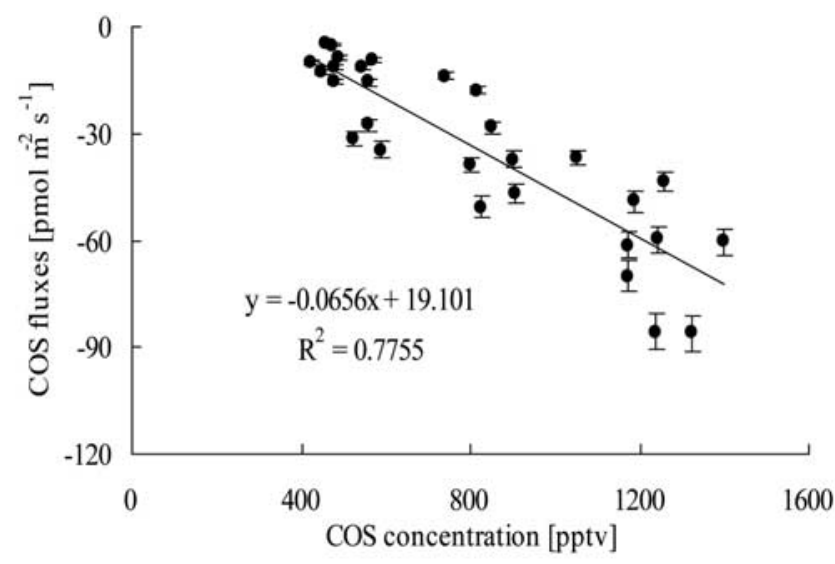

Figure 3. COS exchange correlated to the ambient mixing ratio inside the chamber on 2-24 June 2003.

correlation coefficient $\left(R^{2}\right)$ is $0.78(n=29)$, which implies that the COS concentration has a significant effect on COS uptake $(\alpha=0.001)$. For autumn and spring, the correlation coefficient $\left(R^{2}\right)$ is $0.79(n=19)$ and $0.55(n=32)$, respectively.

[26] The seasonal variation of the COS exchange fluxes were also investigated in this study. Because ambient COS concentration has significant influence on COS uptake, we only select the data when the ambient COS concentrations were from 450 to $600 \mathrm{ppt}$ in daytime for seasonal comparison. The average flux in spring was $27.09 \mathrm{pmol} \mathrm{m}^{-2} \mathrm{~s}^{-1}$ $(n=12)$, which was much higher than $12.98 \mathrm{pmol} \mathrm{m}^{-2} \mathrm{~s}^{-1}$ $(n=13)$ in autumn and $15.23 \mathrm{pmol} \mathrm{m}^{-2} \mathrm{~s}^{-1}(n=13)$ in summer. In spring, the average temperature was near $20^{\circ} \mathrm{C}$, which was in favor of enzyme activity. In autumn, most of the time the temperature was at $10-14^{\circ} \mathrm{C}$. The low COS uptake might be due to the low temperature as well as grass senescence. While in summer, the temperature in the enclosure often exceeded $30^{\circ} \mathrm{C}$. An enzyme increases the turnover with increasing temperature, but this trend is superimposed by a decrease of activity if the temperature range exceeds a certain value owing to reorganization and/ or denaturation of the enzyme structures [Kesselmeier et al., 1999]. The temperature over $30^{\circ} \mathrm{C}$ might have exceeded the optimum temperature for CA enzyme activity. This might be the main reason for the low COS uptake observed in summer.

[27] The vertical profiles of COS obtained on 8 November 2002 gave indirect evidence for COS net uptake by the lawn (Figure 4). The day was under very stable meteorological conditions and was sunny and windless. The samples at different heights (at $0.5 \mathrm{~m}, 4 \mathrm{~m}$, and $12 \mathrm{~m}$ above the lawn) were obtained by using mini pumps simultaneously. The observed shifts in the COS profiles suggest a light- and temperature-dependent absorption of this gas. At 1120 and 1420 LT, when light and temperature were at higher values, the concentration at $0.5 \mathrm{~m}$ was obviously lower than that at $4 \mathrm{~m}$. Comparatively at 0930 and $1630 \mathrm{LT}$, the concentration gradients were smaller, which corresponded with low gas exchanges. Our previous study [Mu et al., 2002] indicated that a significant gradient for COS among the three investigated levels, with high values near the ground and low values at higher altitude, suggest that strong sources of COS at ground in Beijing city exist. The lower concentration at $12 \mathrm{~m}$ than at $4 \mathrm{~m}$ in the afternoon may partly be due to the downward mixing of air from higher layer.

\subsection{Dimethyl Sulfide (DMS) Emission by Lawn}

[28] The DMS concentrations in the atmosphere were often less than the detection limit of our system during our measurements. DMS in the first sample after employment of the static chamber usually couldn't be detected. But DMS could be detected after the enclosure deployed on the lawn for several minutes because of the accumulation of DMS in the enclosure. Most of the DMS fluxes were calculated based on four-headspace air samples.

[29] In the daytime, the fluxes of DMS were higher than during the night (as shown in Figure 2). The average DMS flux in daytime was $0.813 \mathrm{pmol} \mathrm{m}^{-2} \mathrm{~s}^{-1}(n=71)$ with a maximum value of $3.14 \mathrm{pmol} \mathrm{m}^{-2} \mathrm{~s}^{-1}$ and only $0.393 \mathrm{pmol} \mathrm{m}^{-2} \mathrm{~s}^{-1}(n=12)$ in nighttime. Previous studies [Fall et al., 1988; Yang et al., 1998; Kanda et al., 1995; Cooper et al., 1987] also observed same DMS flux pattern for various plants and soils, and they pointed out that DMS emission from various plants increased exponentially with the air temperature within the enclosure. Same phenomenon was also observed in this study in a diurnal cycle on 9 November 2002. The correlation coefficient $\left(R^{2}\right)$ of the logarithmic values of the DMS
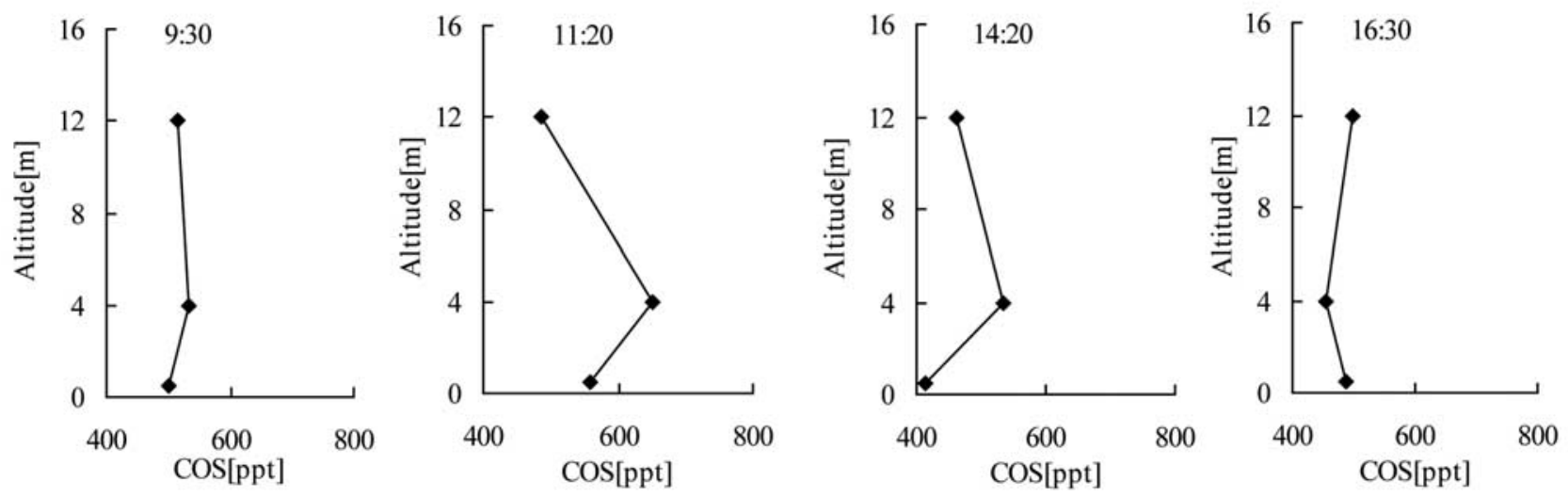

Figure 4. The atmospheric COS concentrations at different altitudes on 8 November 2002. 


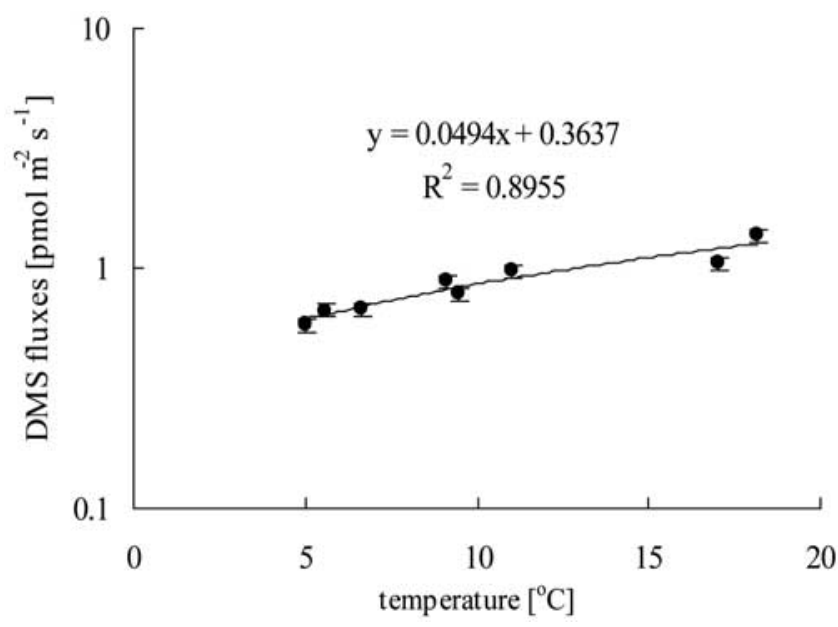

Figure 5. DMS fluxes for lawn as a function of air temperature within the enclosure.

fluxes versus the temperature in the chamber was greater than 0.89 (see Figure 5). However, the correlation between DMS emission and the enclosure temperature for the whole data $(n=83)$ was very poor $\left(R^{2}=0.115\right)$. This result indicated other factors except the enclosure temperature might influence on DMS emission from plants. This conclusion could be further certified by seasonal variation of DMS fluxes. The average DMS flux was 1.18 pmol m $\mathrm{m}^{-2} \mathrm{~s}^{-1}$ in spring $(n=35)$, which was higher than 0.96 pmol m $\mathrm{m}^{-2} \mathrm{~s}^{-1}$ in autumn $(n=12)$ and $0.48 \mathrm{pmol} \mathrm{m}^{-2} \mathrm{~s}^{-1}$ in summer $(n=36)$. The DMS fluxes obtained by this study were in good agreement with previous studies for other plants [Kanda et al., 1995; Gries et al., 1994]. The annual mean DMS emission from maize and wheat was $4.94 \pm 0.50 \times 10^{-3} \mathrm{~g} \mathrm{~m}^{-2} \mathrm{a}^{-1}$ [Kanda et al. 1995], that is $2.53 \pm 0.26 \mathrm{pmol} \mathrm{m}^{-2} \mathrm{~s}^{-1}$. The work of Gries et al. [1994] on lichens yields an annual DMS emission flux of $0.93 \pm 0.62 \times 10^{-12} \mathrm{~g} \mathrm{dw}^{-1} \mathrm{~s}^{-1}$ [Gries et al., 1994]. If a typical output of lichens is $740 \mathrm{~kg} \mathrm{dw} \mathrm{ha}^{-1}$
[Kuhn et al., 1996], this yields a DMS flux from the lichens of $1.11 \pm 0.74 \mathrm{pmol} \mathrm{m}^{-2} \mathrm{~s}^{-1}$.

\subsection{COS Uptake for Soil}

[30] We investigated COS and DMS fluxes for soil from 13 May to 18 June. The results clearly show that the investigated soil (remove grass and the roots) must be regarded as a sink for COS. Figure 6 shows the COS deposition velocities for the soil as well as those for the lawn. The soil biota (fungi and microbes) was active during daytime as well as nighttime and was not dependent on the light regime. The value of COS uptake by soil was under $6.52 \mathrm{pmol} \mathrm{m}^{-2} \mathrm{~s}^{-1}$, which was in the same range as results of other investigators who used dynamic enclosure methods or static methods. The COS uptake for lawn soil in comparison with other soil species was listed in Table 3. The values of Kuhn et al. [1996] were a little higher than others. But they pointed out their values had to be regarded as an upper limit because of the pressure influence on the measured fluxes.

[31] The exact mechanism for the microbial uptake of COS has not been determined. However, CA responsible for the consumption of COS was shown in several microorganisms already [Badger and Price, 1990; Chengelis and Neal, 1979, 1980; Miller et al., 1989; ProtoschillKrebs et al., 1989]. Kesselmeier et al. [1999] regarded the enzyme CA as the dominant factor for the consumption of COS in their investigated soil. Their results indicated that atmospheric COS mixing ratios, temperature, and soil water content were the physicochemical parameters controlling the uptake. Within our field data, further evidence was provided for effects of the three factors. The correlation coefficient $\left(R^{2}\right)$ between the COS exchange fluxes for the soil and the COS mixing ratios was $0.66(n=20)$. Soil temperature was also a very important factor for COS uptake. When soil temperatures were in the range $18.2-20.0^{\circ} \mathrm{C}, 20.1-22.0^{\circ} \mathrm{C}$ and $22.1-25^{\circ} \mathrm{C}$, the average COS deposition velocities for soil were $0.104 \mathrm{~mm} \mathrm{~s}^{-1}$, $0.074 \mathrm{~mm} \mathrm{~s}^{-1}$ and $0.065 \mathrm{~mm} \mathrm{~s}^{-1}$, respectively. These

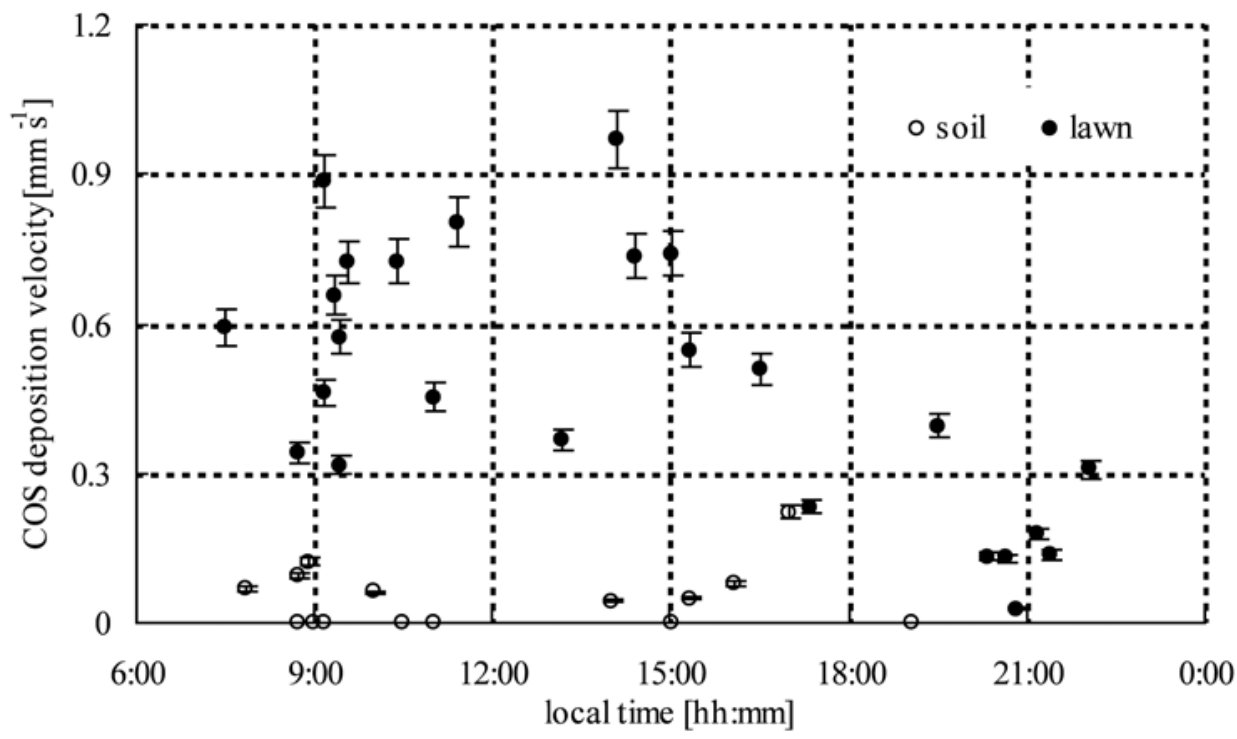

Figure 6. COS deposition velocity of soil as well as of lawn during 2-18 June 2003. Error bars of COS exchange indicate the total flux error according to equation (1). 
Table 3. COS Uptake of Lawn Soil in Comparison With Other Soil Species

\begin{tabular}{lcc}
\hline \multicolumn{1}{c}{ Species } & $\begin{array}{c}\text { Uptake Rate, } \\
\text { pmol m } \mathrm{s}^{-1}\end{array}$ & Reference \\
\hline Lawn soil & $0-6.52$ & this paper \\
Unvegetated forest soil & $1.4-8.4$ & Castro and Galloway [1991] \\
Intact peat soil & $1.25-4.2$ & Fried et al. [1993] \\
Intact peat soil & $1.0-15.3$ & de Mello and Hines [1994] \\
Coniferous boreal forest soils & $2.5 \pm 1.3$ & Simmons et al. [1999] \\
Open oak woodland soil & $8.8-13.3$ & Kuhn et al. $[1996]$ \\
\hline
\end{tabular}

results were in accorded with laboratory study of Kesselmeier et al. [1999]. They found the COS uptake for soil has an optimum temperature range between $16^{\circ}$ and $20^{\circ} \mathrm{C}$, followed by a sharp decrease at higher temperatures. Soil moisture also has an important impact on COS uptake with optimum moisture around $12.5 \%$ as reported by Kesselmeier et al. [1999]. The large variation of COS fluxes $\left(0-6.52 \mathrm{pmol} \mathrm{m}^{-2} \mathrm{~s}^{-1}\right)$ for the soil measured by this study might be partly due to the different soil moisture. Although we didn't measure the soil moisture during our experiment, the impact of soil moisture could be seen in our results, for example, even under high mixing ratio of $\mathrm{COS}$ and at optimum temperature around $19^{\circ} \mathrm{C}$, most of the low values of COS fluxes were obtained when the soil became dry.

[32] Because of the large variation of the mixing ratios of COS during our experiments (the variation of COS mixing ratios from $480 \mathrm{ppt}$ to $1396 \mathrm{ppt}$ ), we did not observe a clear COS uptake diurnal cycle for the soil.

[33] There is sufficient evidence to suggest that COS uptake by vegetation is a major tropospheric sink for COS on a global basis [de Mello and Hines, 1994; Fall et al., 1988; Fried et al., 1993; Goldan et al., 1988, 1987; Hines and Morrison, 1992; Morrison and Hines, 1990]. Further evidence for the important role of vegetation was provided in this study. Comparing the deposition velocities for the soil with that for the lawn (Figure 6), it was evident that the lawn consumed COS at significantly faster rates than the nonvegetated soil (with a difference in means of $17.34 \mathrm{pmol} \mathrm{m}^{-2} \mathrm{~s}^{-1}$ ).

[34] As for DMS, the DMS concentration within the static enclosure employed on soil was under the detection limit of our analysis system. So we didn't obtain DMS fluxes for the soil during our experiment.

\section{Conclusion}

[35] We investigated the COS uptake and DMS emission between the lawn and the atmosphere during November 2002 to June 2003. The results indicated that the lawn acted as a sink for atmospheric COS and a source of DMS. The exchange fluxes of COS and DMS ranged between $-3.24 \mathrm{pmol} \mathrm{m}^{-2} \mathrm{~s}^{-1}$ and $-94.52 \mathrm{pmol} \mathrm{m}^{-2} \mathrm{~s}^{-1}$, and between 0 and 3.14 pmol m $\mathrm{m}^{-2} \mathrm{~s}^{-1}$, respectively. The deposition velocity of COS was in the range from 0.11 to $2.05 \mathrm{~mm} \mathrm{sec}^{-1}$. The COS concentration has significant effect on COS uptake $(\alpha=0.001)$ for three seasons. The lawn was capable of continuously absorbing COS in the dark as well as in the light, which implied a light-independent stomatal regulation. The average COS and DMS fluxes were much higher in spring than in autumn and in summer. This seasonal variation might be ascribed to the different temperature as well as the grass age. The daytime vertical profiles of COS also indicate that the lawn acted as a net sink for COS.

[36] Soil also acted as a sink for COS during our study. However, the COS exchange fluxes of the lawn were much higher than that of the soil with a difference in means of 17.34 pmol m $\mathrm{m}^{-2} \mathrm{~s}^{-1}$.

[37] The maximum DMS emission flux for the lawn was $3.14 \mathrm{pmol} \mathrm{m} \mathrm{m}^{-2} \mathrm{~s}^{-1}$. The dependency of DMS emission fluxes on temperature was observed in Nov. 2002. No DMS emission was observed from the soil.

[38] Acknowledgments. This work was supported by grants from NSF (China) (20277044, 20177028, 40275038), National Basic Research and Development Program-2002CB410803973, Innovation program of Chinese Academy of Sciences (KZCX2-414).

\section{References}

Badger, M. R., and G. D. Price (1990), Carbonyl oxysulfide is an inhibitor of both $\mathrm{CO}_{2}$ and $\mathrm{HCO}_{3}$ : Uptake in the cayno-bacterium Synechococcus PCC7942, Plant Physiol., 94, 35-39.

Berresheim, H., and V. D. Vulcan (1992), Vertical distributions of COS, $\mathrm{CS}_{2}$, DMS and other sulfur compounds in a loblolly pine forest, Atmos. Environ., Part A, 26(11), 2031-2036.

Castro, M. S., and J. N. Galloway (1991), A comparison of sulfur-free and ambient air enclosure techniques for measuring the exchange of reduced sulfur gases between soils and the atmosphere, J. Geophys. Res., 96, $15,427-15,437$.

Chengelis, C. P., and R. A. Neal (1979), Hepatic carbonyl sulphide metabolism, Biochem. Biophys. Res. Comm., 90, 993-999.

Chengelis, C. P., and R. A. Neal (1980), Studies of carbonyl sulphide toxicity: Metabolism by carbonic anhydrase, Toxicol. Appl. Pharmacol., $55,198-202$.

Conrad, R. (1994), Compensation concentration as a critical variable for regulating the flux of trace gases between soil and atmosphere, Biogeochemistry, 27, 155-170.

Cooper, D. J., D. S. Saltzman, W. Z. DeMell, W. J. Cooper, D. L. Savoie, R. Zika, and J. M. Prospero (1987), Emissions from biogenic sulfur compounds from several wetland soils in Florida, Atmos. Environ., 21, $1494-1495$.

Crutzen, P. J. (1976), The possible importance of CSO for the sulfate layer of the stratosphere, Geophys. Res. Lett., 3, 73-76.

de Mello, W. Z., and M. E. Hines (1994), Application of static and dynamic enclosures for determining dimethyl sulfide and carbonyl sulfide exchange in Sphagnum peatlands: Implications for the magnitude and direction of flux, J. Geophys. Res., 99, 14,604-14,607.

Doerffel, K. (1984), Statistik in der Analytischen Chemie, 3rd ed., Verlag Chem., Weinheim, Germany.

Fall, R., D. L. Albitton, R. C. Fehsenfeld, W. C. Kuster, and P. D. Goldan (1988), Laboratory studies of some environmental variables controlling sulfure emissions from plants, J. Atmos. Chem., 6, 341-362.

Fried, A., L. F. Klinger, and D. J. Erisckson III (1993), Atmospheric carbonyl sulfide exchange in bog microcosm, Geophys. Res. Lett., 20, 129132 .

Goldan, P. D., W. C. Kuster, D. L. Albritton, and F. C. Fehsenfeld (1987), The measurement of natural sulfur emissions from soil and vegetation: Three sites in the eastern United States revisited, J. Atmos. Chem., 5, $439-467$.

Goldan, P. D., R. Fall, W. C. Kuster, and F. C. Fehsenfeld (1988), Uptake of COS by growing vegetation: A major tropospheric sink, J. Geophys. Res., 93, 14,186-14,192.

Gries, C., T. H. Nah III, and J. Kesselmeier (1994), Exchange of reduced sulfur gases between lichens and the atmosphere, Biogeochemistry, 26, $25-39$.

Hines, M. E., and M. C. Morrison (1992), Emissions of biogenic sulfur gases from Alaskan Tundra, J. Geophys. Res., 97, 16,70316,707 .

Hofmann, U. (1993), Der Austausch von reduzierten Schwefel-Verbindungen zwischen Vegetation und Atmosphäre: Interpretaion von Versuchen im Freiland in Verbindung mit mechanistischen Experimenten im Labor., Ph.D. thesis, Johannes Gutenberg Univ., Mainz, Germany.

Huber, B. (1994), Austausch flüchtiger Schwefelverbindungen in landund forstwirtschaftlichen Ökosystemen, Ph.D. thesis, Univ. of Munich, Germany.

Kanda, K., H. Tsuruta, and K. Minami (1995), Emissions of DMS, OCS and $\mathrm{CS}_{2}$ from maize and wheat fields, Soil Sci. Plant Nutr., 41, 1-8. 
Kesselmeier (1999), Carbonyl sulfide exchange on an ecosystem scale: Soil represents a dominant sink for atmospheric OCS, Atmos. Environ., 33 $995-1008$.

Kesselmeier, J., and L. Merk (1993), Exchange of COS between agriculture plants and the atmosphere: Studies on the deposition of COS to peas, corn and rapeseed, Biogeochemistry, 23, 47-59.

Kesselmeier, J., F. X. Meixner, U. Hofmann, A. L. Ajavon, S. Leimbach, and M. O. Andreae (1993), Reduced sulfur compound exchange between the atmosphere and tropical tree species in southern Cameroon, Biogeochemisty, 23, 23-45.

Kesselmeier, J., N. Teusch, and U. Kuhn (1999), Controlling variables for the uptake of atmospheric carbonyl sulfide by soil, J. Geophys. Res., 104, $11,577-11,584$

Kittler, R. P., H. Swan, and J. Ivey (1992), An indicating oxidant scrubber for the measurement of atmospheric dimethylsulphide, Atmos. Environ., Part A, 26(14), 2661-2664.

Kluczewski, S. M., K. A. Brown, and J. N. Bell (1985), Deposition of (35S)-carbonyl sulfide to vegetable groups, Radiat. Prot. Dosi., 11, $173-177$.

Kuhn, U., C. Ammann, A. Wolf, F. X. Meixner, M. O. Andreae, and J. Liu (1996), Soil Physical and Chemical Analysis andDescription of Soil Profiles, Stand. Press of Chin., Beijing.

Miller, A. G., G. S. Espie, and D. T. Canvin (1989), Use of carbon oxysuldide, a structural analog of $\mathrm{CO} 2$, to study active $\mathrm{CO}_{2}$ transport in the cyanobacterium Synechococcus UTEX 625, Plant Physiol., 90, 12211231

Morrison, M. C., and M. E. Hines (1990), The variability of biogenic sulfur flux from a temperate salt marsh on short time and space scales, Atmos. Environ., 24, 1771-1779.

Mu, Y. H., H. Wu, W. Zhang, and G. Jiang (2002), Impact of anthropogenic sources on carbonyl sulfide in Beijing city, J. Geophys. Res., 107(D24), 4769, doi:10.1029/2002JD002245.
Protoschill-Krebs, G., C. Wilhelm, and J. Kesselmeier (1989), Consumption of COS by higher plant carbonic anyhydrase (CA), Atmos. Environ., 30(N18), 3151-3156.

Remde, A., F. Slemr, and R. Conrad (1996), Microbial production and uptake of nitric oxide in soil, FEMS Microbiol. Ecol., 62, 221-230.

Roche, A. E. (1994), Observations of lower-stratospheric CINO, $\mathrm{HNO}_{3}$ and aerosol by the UARS CLAES experiment between January, 1992, and April, 1993, J. Atmos. Sci., 51, 2877-2902.

Simmons, J. S., L. Klemedtsson, H. Hultberg, and M. E. Hines (1999), Consumption of atmospheric carbonyl sulfide by coniferous boreal forest soils, J. Geophys. Res., 104, 11,569-11,576.

Solomon, S., R. W. Sanders, R. R. Garcia, and J. G. Keys (1993), Increased chlorine dioxide over Antarctica caused by volcanic aerosols from Mount Pinatubo, Nature, 363, 245-248.

Tangerman, A. (1986), Determination of volatile sulphur compound in air at the parts per trillion level by tenax trapping and gas chromatography, J. Chromatogr., 366, 205-216.

Turco, R. P., R. C. Witten, O. B. Toon, J. B. Pollack, and P. Hamill (1980), OCS, stratospheric aerosols and climate, Nature, 283, 283-286.

Tylor, G. E., S. B. McLaughlin, D. S. Shriner, and W. J. Selvidge (1983), The flux of sulfur-containing gases to vegetation, Atmos. Environ., 17, $789-796$.

Watts, S. F. (2000), The mass budgets of carbonyl sulfide, dimethyl sulfide, carbon disulfide and hydrogen sulfide, Atmos. Environ., 34, 761-779.

Yang, Z., L. Kong, J. Zhang, L. Wang, and S. Xi (1998), Emission of biogenic sulfur gases from Chinese rice paddies, Sci. Total Environ., $224,1-8$.

C. Geng and Y. Mu, Research Center for Eco-Environmental Sciences, Chinese Academy of Sciences, Beijing 100085, China. (yjmu@mail.rcees. ac.cn) 